Section Editor Mitchell S.V. Elkind, MD, MS

Yousef Hannawi, MD Stelios M. Smirnakis, $\mathrm{MD}, \mathrm{PhD}$

Correspondence to Dr. Hannawi: hannawi@bcm.edu

\title{
Emerging Subspecialties: Neuroinformatics
}

DEFINITION AND HISTORICAL OVERVIEW In the last few years, there has been an overwhelming influx of advanced genomics and brain imaging research data. The evolution of computational infrastructures needed to accompany neuroscience data growth eventually led to the birth of neuroinformatics. ${ }^{1}$ Neuroinformatics combines neuroscience and informatics research to develop innovative tools for organization of large-volume, high-dimensional neuroscience data. It also applies computational models to integrate and analyze these data to eventually understand brain structure and function. ${ }^{2}$

The birth of the field of neuroinformatics came about through a study performed by the National Academy of Sciences, whose purpose was to evaluate the need to create databases for sharing primary neuroscience research data. The study concluded that the capability of information technology to handle the complexity of such data had matured, and that such a program would play a critical role in understanding normal brain development and function as well as the diagnosis, treatment, and prevention of nervous system disorders. ${ }^{2}$ This positive result enabled the National Institute of Mental Health, with support of other NIH institutes, the National Science Foundation, The National Aeronautics and Space Administration, and the Department of Energy to launch the Human Brain Project (HBP) in 1993. The name neuroinformatics was coined and the new approach rapidly spread in Europe and the rest of the world. Since then, many distinct informatics programs have been initiated at the $\mathrm{NIH}$ and other government agencies (table).

More recently, informatics applications have extended to involve different fields of clinical neurology and many academicians started research careers in them. Training programs were created for the interested neuroscience students and the field started to take its shape. We discuss the field by reviewing some of its successful applications in neuroscience and clinical neurology. Then we briefly go over the current status of training in the field.

INFORMATICS IN NEUROSCIENCE The end goal of neuroinformatics is to help understand brain function in health and disease. This includes efficiently analyzing different levels of complex interactions that occur in cellular biology, cortical microcircuits, global brain networks, and cognitive processes. ${ }^{2,3}$ In order to achieve this goal, it is essential to 1) create large databases where it is possible to share diverse, carefully standardized, primary neuroscience data, 2) develop powerful analysis tools, and 3) develop computational models. These 3 categories form neuroinformatics' main focus. ${ }^{4,5}$

Multiple projects have been developed to store different types of data, such as The National fMRI Data Center and Cell-Centered Database (table). ${ }^{6}$ We describe briefly the organization of the SenseLab project to illustrate the structure of a typical neuroinformatics database. SenseLab was founded in 1993 as a part of the original HBP to study membrane properties that mediate information processing in the nerve cells by using the olfactory pathway as a model system. "SenseLab: Integration of multidisciplinary sensory data" is a multidisciplinary project based at Yale University in New Haven, Connecticut. It includes a number of specialized databases that share the same structure, so there is continuous navigation among them. These databases can be categorized in 2 groups: neuronal and olfactory. The neuronal databases cover pharmacology, ion channels, cell properties, and neuronal models, while the olfactory group contains information about odor maps and receptors. Within the neuronal databases, entries are linked across the different subcategories they belong to. Odorant molecule information is linked to specific receptors, and cross-referenced to another archive containing images of the olfactory bulb activity patterns in response to various combinations of odorant presentations. ${ }^{6,7}$ The resulting information can be used to construct realistic biological models of the olfactory neuronal network activity.

For these large databases to be useful, it is critical to be able to search them efficiently. The neuroscience database gateway was initiated by the Society of Neuroscience for this purpose and transitioned later to an enhanced platform, the Neuroscience Information Framework, which allows users to navigate efficiently through multiple databases (table). The International Neuroinformatics Coordinating Facility (INCF) was established to promote sharing

From the Departments of Neurology (Y.H., S.M.S.) and Neuroscience (S.M.S.), Baylor College of Medicine, Houston, TX.

Go to Neurology.org for full disclosures. Funding information and disclosures deemed relevant by the authors, if any, are provided at the end of the article. 
Table Examples of ongoing projects and resources available for neuroinformatic researchers and applicants

\begin{tabular}{|c|c|c|c|}
\hline Category & Resource & Web site & Description \\
\hline \multirow[t]{2}{*}{ Training } & $\begin{array}{l}\text { International Neuroinformatics } \\
\text { Coordinating Facility (INCF) }\end{array}$ & $\begin{array}{l}\text { www.incf.org/resources/ } \\
\text { training }\end{array}$ & $\begin{array}{l}\text { Openings for various training programs including } \mathrm{PhD} \text {, Master, } \\
\text { undergraduate, and short courses are published online on this } \\
\text { Web site }\end{array}$ \\
\hline & Neuroinformatics site & www.neuroinf.org & $\begin{array}{l}\text { Provides the international neuroinformatics community with } \\
\text { information and access to courses and workshops }\end{array}$ \\
\hline \multirow{5}{*}{$\begin{array}{l}\text { Databases, } \\
\text { computational } \\
\text { infrastructures, } \\
\text { and ongoing } \\
\text { projects }\end{array}$} & Cell-Centered Database & www.ccdb.ucsd.edu & $\begin{array}{l}\text { Provides options for storing and mining cellular and subcellular } \\
\text { data derived from light and electron microscopy }\end{array}$ \\
\hline & The National fMRI Data Center & www.fmridc.org & $\begin{array}{l}\text { Provides a repository where all neuroscience imaging data can } \\
\text { be archived and shared }\end{array}$ \\
\hline & $\begin{array}{l}\text { Brain Molecular Anatomy } \\
\text { Project (BMAP) }\end{array}$ & Trans.nih.gov/bmap & $\begin{array}{l}\text { Aims at discovery of all the genes expressed in the CNS in addition } \\
\text { to analysis of their roles }\end{array}$ \\
\hline & $\begin{array}{l}\text { The Cancer Genome Atlas } \\
\text { (TCGA) }\end{array}$ & Cancergenome.nih.gov & $\begin{array}{l}\text { Aims to create a genomic database combining different human } \\
\text { cancers including glioblastoma }\end{array}$ \\
\hline & $\begin{array}{l}\text { Repository of Molecular BRAin } \\
\text { Neoplasia DaTa (REMBRANDT) }\end{array}$ & $\begin{array}{l}\text { Caintegrator-info.nci.nih. } \\
\text { gov/rembrandt }\end{array}$ & $\begin{array}{l}\text { A large-scale project that combines molecular and clinical trial } \\
\text { research data related to brain cancers; aims to understand the } \\
\text { critical correlation among them by using advanced Web-based } \\
\text { analysis tools }\end{array}$ \\
\hline \multirow[t]{2}{*}{$\begin{array}{l}\text { Organizations and } \\
\text { online resources for } \\
\text { data navigation }\end{array}$} & $\begin{array}{l}\text { International Neuroinformatics } \\
\text { Coordinating Facility (INCF) }\end{array}$ & www.incf.org & $\begin{array}{l}\text { INCF collects available neuroinformatics tools in the INCF } \\
\text { software center (software.incf.org) where anyone can upload } \\
\text { documentations and track use of the software }\end{array}$ \\
\hline & $\begin{array}{l}\text { Neuroscience Information } \\
\text { Framework (NIF) }\end{array}$ & www.neuinfo.org & $\begin{array}{l}\text { NIF is an inventory of Web-based neuroscience resources including } \\
\text { data, materials, and tools }\end{array}$ \\
\hline
\end{tabular}

data and making computational infrastructures available to the international research community. As a result of these efforts, a significant number of publications have come out and specialized journals, such as the Journal of Neuroinformatics, have been established to accommodate the field's rapid growth.

INFORMATICS IN CLINICAL NEUROLOGY There are numerous ongoing projects involving neuroinformatics in clinical neurology ranging from neurocritical care to neurodegenerative diseases to neuro-oncology (table). We discuss briefly applications to neurocritical care and to neurodegenerative diseases.

Informatics in neurocritical care. Multimodal monitoring is an important component of the neurointensive care unit. Many parameters are followed including blood pressure, heart rate, intracranial pressure, and cerebral perfusion pressure. Because of the large number of monitored variables, length of hospital stay, and high frequency of sampling, the analysis of the collected data is challenging.

Informatics applications aim to find ways to integrate and interpret these complex data to come up with formulas that can be translated into meaningful clinical information. ${ }^{8}$ This analysis can be performed using various statistical methods such as regression analysis, decision tree analysis, neural networks, and numerous other advanced methods. For example, decision tree analysis has been used to successfully predict outcome in traumatic brain injury (TBI) patients. Its results are similar to those of logistic regression analysis based on different variables such as pupil examination on admission and age. ${ }^{8}$

More advanced data analysis methods envision the patient as transitioning among different physiologic and pathologic states. Treatment directs the patient into a more favorable state. This combines dynamic system modeling and a systematic real-time classification process for understanding the patient condition. A novel clinical application of these methods is the ongoing European Avert-IT project, which uses various patient parameters to predict the risk of hypotension among TBI patients with the aim of decreasing secondary brain injury. ${ }^{8}$

Informatics in neurodegenerative diseases. Neuroimaging data input has increased greatly in the field of neurodegenerative diseases during the last few years. To analyze these data, it is important to have an unrestricted access policy to a pool of large well-standardized data that originates from different centers. ${ }^{9}$ The Alzheimer's Disease Neuroimaging Initiative (ADNI) database represents a major step in achieving this aim. It has an unprecedented worldwide policy of open access to its database, which includes blood and CSF test results, as well as MRI/PET imaging data. The hope is that integrating these data appropriately will allow researchers to better define and predict the rate of cognitive impairment, to improve the design of clinical trials, and to eventually come up with more effective therapies.

An important step for taking advantage of these emerging databases is providing neuroscientists with appropriate tools for analysis, including algorithms, computational infrastructures, and statistical methods, 
through developing international service infrastructures. Currently, there are 3 software packages open for public access developed at different times: LONI, NeuGrid, and CBRAIN are located in the United States, Europe, and Canada, respectively. These packages share some common features but each has different specifics. We briefly describe LONI since it is the largest, most developed one and hosts, among others, the ADNI database. It is located physically at UCLA. LONI is developing methods for imaging analysis for both healthy subjects and patients with neurologic and psychiatric diseases. The LONI workflow management system enables automated measurement of functional and morphometric analysis, dynamic assessment of brain volume and shape features, as well as extraction and association between cognitive, genetic, and clinical biomarkers. ${ }^{9}$

TRAINING OPPORTUNITIES Designing ways to handle complex neuroinformatics questions and datasets requires scientific sophistication. A recent report from the INCF (www.incf.org) highlights the importance of training in the field. Short training courses are held across Europe and the United States, each focusing on particular aspects of neuroinformatics. Formal training programs also exist conferring the undergraduate, Master, or $\mathrm{PhD}$ degrees. Background in neuroscience, quantitative methods, and computer science is useful to have, but can also be acquired in the process. Openings are posted on the INCF Web site and students can apply to them directly (table). At present, there is no established formal fellowship curriculum in neuroinformatics for clinical neurologists. Academic neurologists entering the field typically work on particular applications and they acquire the necessary expertise via a combination of 1) hands-on experience with a project, 2) one-on-one mentoring, and 3) neuroinformatics curricula available in their area.

DISCUSSION The rapid growth of neuroscientific data has led to a new, data-mining-oriented approach to research that is different from the classical hypothesis-driven approach. The neuroinformatics field has to overcome considerable difficulties associated with the heterogeneity of collected data, the principles of primary data sharing, and the complexity of analysis. However, it has already been established as a field, is currently at the beginning of its exponential growth, and is bound to result in numerous important advances in neuroscience and clinical neurology. It is a challenging and gratifying field for uprising residents and fellows committed to moving the neurology field forward.

\section{AUTHOR CONTRIBUTIONS}

Yousef Hannawi: drafting/revising the manuscript. Stelios M. Smirnakis: drafting/revising the manuscript, study concept or design, analysis or interpretation of data, study supervision.

\section{STUDY FUNDING}

No targeted funding reported.

\section{DISCLOSURE}

Y. Hannawi reports no disclosures. S. Smirnakis received funds from the NIH, Howard Hughes Medical Institute, Department of Defense, the March of Dimes, and the Simons and TIRR Foundations. Dr. Smirnakis consulted occasionally for Amgen, Inc. Go to Neurology.org for full disclosures.

\section{REFERENCES}

1. Wood H. A rapid e-volution. Nat Rev Neurol 2011;7:415.

2. Crasto CJ, Koslow SH. Neuroinformatics (Methods in Molecular Biology). Totowa, NJ: Humana Press Inc; 2007.

3. Koslow SH, Subramaniam S. Databasing the Brain: From Data to Knowledge (Neuroinformatics). Hoboken, NJ: Wiley;2005.

4. Koslow SH. Discovery and integrative neuroscience. Clin EEG Neurosci 2005;36:55-63.

5. Bjaalie JG, Grillner S. Global Neuroinformatics: The International Neuroinformatics Coordinating Facility. J Neurosci 2007;27:3613-3615.

6. Morse TM. Neuroinformatics: from bioinformatics to databasing the brain. Bioinform Biol Insights 2008;2:253-264.

7. French L, Pavlidis P. Informatics in neuroscience. Brief Bioinform 2007;8:446-456.

8. Hemphill JC, Andrews P, De Georgia M, Medscape. Multimodal monitoring and neurocritical care bioinformatics. Nat Rev Neurol 2011;7:451-460.

9. Frisoni GB, Redolfi A, Manset D, Rousseau ME, Toga A, Evans AC. Virtual imaging laboratories for marker discovery in neurodegenerative diseases. Nat Rev Neurol 2011;7: 429-438. 


\title{
Neurology
}

\author{
Emerging Subspecialties: Neuroinformatics \\ Yousef Hannawi and Stelios M. Smirnakis \\ Neurology 2013;80;e166-e168 \\ DOI 10.1212/WNL.0b013e31828c2f2e
}

This information is current as of April 8, 2013

Updated Information \&
Services

References

Subspecialty Collections

Permissions \& Licensing

Reprints including high resolution figures, can be found at: http://n.neurology.org/content/80/15/e166.full

This article cites 7 articles, 1 of which you can access for free at: http://n.neurology.org/content/80/15/e166.full\#ref-list-1

This article, along with others on similar topics, appears in the following collection(s):

All Cognitive Disorders/Dementia

http://n.neurology.org/cgi/collection/all_cognitive_disorders_dementia Critical care

http://n.neurology.org/cgi/collection/critical_care

Information about reproducing this article in parts (figures,tables) or in its entirety can be found online at:

http://www.neurology.org/about/about_the_journal\#permissions

Information about ordering reprints can be found online:

http://n.neurology.org/subscribers/advertise

Neurology ${ }^{\circledR}$ is the official journal of the American Academy of Neurology. Published continuously since 1951, it is now a weekly with 48 issues per year. Copyright @ 2013 American Academy of Neurology. All rights reserved. Print ISSN: 0028-3878. Online ISSN: 1526-632X.

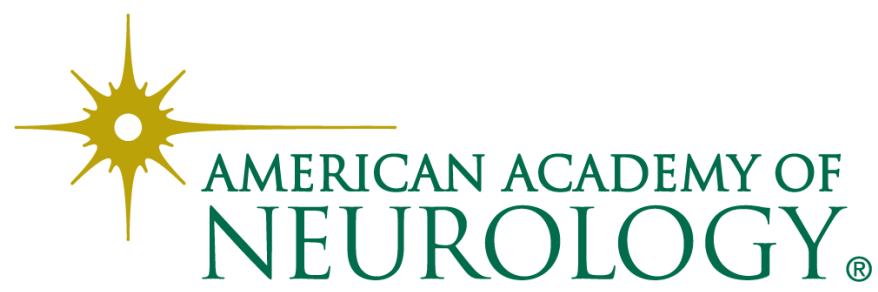

